\title{
ANALISIS SENTIMEN ULASAN APLIKASI TIKTOK DI GOOGLE PLAY MENGGUNAKAN METODE SUPPORT VECTOR MACHINE (SVM) DAN ASOSIASI
}

\author{
Sola Fide ${ }^{1}$, Suparti ${ }^{2}$, Sudarno ${ }^{3}$ \\ ${ }^{1,2,3}$ Departemen Statistika, Fakultas Sains dan Matematika, Universitas Diponegoro \\ solafide34@gmail.com
}

\begin{abstract}
Corona virus pandemic requires people to do activities from home so the number of internet usage in Indonesia has increased because information is carried out through social media. One of the popular social media in Indonesia is TikTok. However, the Tiktok's popularity cannot be separated from the footsteps of TikTok in Indonesia which was blocked by government for committing many violations. Each application allows users to provide a review about the application. To find out the users TikTok's sentiment, sentiment analysis was carried out to classify reviews into positive and negative sentiments. Classification is carried out using the Support Vector Machine (SVM) with kernel Radial Basis Function (RBF) method which is more effective classification algorithm and kernel function, seen from previous studies. The parameters used in the SVM gamma default 0.0004255 and the Cost (C) parameter experiment used is 0,$01 ; 0,1 ; 1 ; 10 ; 100 ; 1000$. The results can provide information that can be retrieved using the association method. The steps are scrapping data, data preprocessing, sentiment scoring, TFIDF weighting, classifying using the SVM RBF kernel method and text association. Evaluation of the model using a confusion matrix with the value of accuracy and kappa. The greater the value of accuracy and kappa, the better the performance of the classification model. The review classification resulted in the best accuracy rate of $90.62 \%$ and the best kappa of $81.24 \%$ which means that it includes an almost perfect classification result. Based on the data association, positive reviews are given because users like and are comfortable with the current version of TikTok which contains funny videos on fyp. Meanwhile, negative reviews were given because the user failed to register and his account was blocked, so the user asked TikTok to continue to make improvements.
\end{abstract}

Keywords: TikTok, sentiment analysis, Suport Vector Machine (SVM), TF-IDF, accuracy, kappa, association

\section{PENDAHULUAN}

Pandemi virus corona menyebabkan terjadinya perubahan di masyarakat. Perubahan didukung dengan berkembangnya teknologi komunikasi yang membuat angka penggunaan internet meningkat yang mendorong persebaran informasi dengan sangat cepat melalui media social. Salah satu media sosial yang populer di Indonesia adalah aplikasi TikTok. Kepopuleran aplikasi TikTok tersebut tidak bisa lepas dari jejak TikTok di Indonesia yang sempat diblokir oleh pemerintah karena dianggap banyak melakukan pelanggaran, seperti pornografi, pelecehan agama, dan lainnya (CNN, 2018). Jumlah pengguna TikTok di Indonesia makin meningkat terlebih di masa pandemi. Menurut laporan perusahaan riset pasar aplikasi mobile Sensor Tower, pada periode Juli 2020, jumlah pengguna TikTok di Indonesia sebanyak 8,5 persen, terbanyak kedua setelah Amerika sebanyak 9,7 persen (Liputan 6, 2020). Berdasarkan pernyataan di atas, penulis akan meneliti bagaimana sentimen ulasan pengguna TikTok di Google Play dengan analisis sentimen. 
Pada penelitian ini dilakukan klasifikasi ulasan pengguna TikTok ke dalam dua sentimen, yaitu sentimen positif dan sentimen negatif. Pengklasifikasian dilakukan dengan metode Support Vector Machine (SVM). SVM adalah algoritma yang sudah mendapatkan pengakuan luas untuk klasifikasi dengan akurasi yang baik. Umumnya, masalah dalam dunia nyata jarang yang bersifat linear separable. Untuk menyelesaikan problem nonlinear, SVM dimodifikasi dengan memasukkan fungsi kernel RBF, yang bisa membuat klasifikasi menggunakan SVM dapat beroperasi dalam ruang dimensi tinggi (Wang, 2005). Selanjutnya dilakukan eksplorasi data ulasan menggunakan metode asosiasi teks untuk mencari kata-kata berhubungan yang dapat memberikan informasi hubungan antarkata dalam ulasan sebagai bahan rujukan dalam proses evaluasi aplikasi (Santosa dan Nugroho, 2019).

\section{TINJAUAN PUSTAKA}

\subsection{Analisis Sentimen}

Analisis sentimen adalah metode untuk mengekstrak opini dan sentimen dari teks bahasa alami menggunakan metode komputasi. Opini dan sentimen terkait dengan evaluasi, penilaian, sikap, pengaruh, emosi, dan suasana hati (Liu, 2015).

\subsection{Text Mining}

Text mining adalah proses mengekstrak informasi melalui identifikasi dan eksplorasi pola yang menarik dari sumber data berupa kumpulan dokumen data tekstual tidak terstruktur. Preprocessing data dilakukan untuk mengubah data tidak terstruktur menjadi lebih terstruktur sehingga data siap diproses. Preprocessing yang dilakukan adalah case folding, cleaning, dan normalisasi kata. Case folding yaitu proses penyeragaman bentuk huruf pada dokumen. Cleaning yaitu penghapusan karakter selain yang ditentukan, seperti huruf atau karakter di luar dari alfabet a-z, tanda baca, angka, dan emoticon. Normalisasi kata yaitu perbaikan kata yang tidak sesuai pedoman (Fatmawati dan Affandes, 2017).

\subsection{Sentiment Scoring}

Sentiment scoring dilakukan dengan menggunakan kamus sentimen dan boosterwords. Kamus sentimen berisi kumpulan kata yang telah diberi kekuatan sentimen, yaitu kekuatan negatif antara -1 hingga -5 dan kekuatan positif antara +1 hingga +5 . Boosterwords adalah kata yang dapat meningkatkan atau mengurangi intensitas sentimen kata di sebelahnya dengan bobot 1-2 (Wahid dan Azhari, 2016).

\subsection{Feature Selection}

Feature selection merupakan tahapan untuk mengurangi dimensi data tekstual sehingga hasil text mining berkualitas lebih baik. Feature selection yang dilakukan adalah stopword removal, stemming, dan tokenizing. Stopword removal adalah tahap menghilangkan kata-kata yang dianggap tidak menggambarkan isi kalimat. Stemming adalah tahap menghilangkan imbuhan kata untuk mendapatkan kata dasar. Tokenizing adalah tahap pemisahan setiap kata dalam suatu kalimat (Indraloka dan Santosa, 2017).

\subsection{Pembobotan Term Frequency-Inverse Document Frequency (TF-IDF)}

Term frequency (tf) merupakan sistem pembobotan yang mengukur frekuensi kemunculan istilah dalam dokumen. Semakin tinggi tf berarti term sering muncul maka dapat dianggap term umum sehingga tidak penting nilainya. Inverse Document Frequency (idf) merupakan frekuensi berbanding terbalik. Persamaan TF-IDF (Christian et al., 2016). 


$$
\begin{aligned}
& T F=\frac{\text { jumlah term } \text { di dok }}{\text { jumlah seluruh term } \text { di } d o k} \\
& I D F=\log _{2} \frac{\text { jumlah seluruh dok }}{\text { jumlah dok pada term }} \\
& T F I D F=T F \times I D F
\end{aligned}
$$

\subsection{Support Vector Machine (SVM)}

SVM adalah metode supervised learning yang menghasilkan fungsi pemetaan berupa fungsi klasifikasi melalui pembuatan hyperplane dengan margin maksimum (Wang, 2005). Margin adalah jarak antara hyperplane dengan pattern terdekat masing-masing kelas. Pattern yang paling dekat ini disebut sebagai support vector (Nugroho et al., 2003).

\subsubsection{SVM Linearly Separable Data}

Linearly separable data adalah data yang dapat dipisahkan secara linear. Misalkan $x_{i} \in R^{d}$ dan label kelas sebagai $y_{i} \in\{-1,+1\}$ untuk $i=1,2, \ldots, n, n$ adalah banyaknya data. Model linier metode SVM untuk menghasilkan hyperplane (Wang, 2005).

$$
y_{i}=\mathbf{w}^{T} \mathbf{x}_{i}+b, \quad i=1,2, . ., n
$$

dengan $\mathbf{w} \quad$ : vektor parameter bobot

$\mathbf{x}_{i} \quad$ : vektor variabel bebas

b : bias atau error

$y_{i} \in\{-1,+1\}$ : nilai target dari himpunan data $\boldsymbol{x}$

Diasumsikan kedua kelas -1 (positif) dan +1 (negatif) terpisah secara sempurna oleh hyperplane $\mathbf{w}^{T} \mathbf{x}+b=0$ (Wang, 2005). Jika $\mathbf{w}^{T} \mathbf{x}_{\mathbf{1}}+b=+1$ adalah hyperplane-pendukung dari kelas +1 (positif) dan $\mathbf{w}^{T} \mathbf{x}_{2}+b=-1$ hyperplane-pendukung dari kelas -1 (negatif), margin dihitung dengan mencari jarak kedua hyperplane-pendukung kedua kelas.

$$
\begin{aligned}
& \mathbf{w}^{T} \mathbf{x}_{\mathbf{1}}+b=+1 \\
& \frac{\mathbf{w}^{T} \mathbf{x}_{\mathbf{2}}+b=-1}{\mathbf{w}^{T}\left(\mathbf{x}_{\mathbf{1}}-\mathbf{x}_{\mathbf{2}}\right)=2}- \\
& \left(\frac{\mathbf{w}}{\|\mathbf{w}\|}\left(\mathbf{x}_{\mathbf{1}}-\mathbf{x}_{\mathbf{2}}\right)\right)=\frac{2}{\|\mathbf{w}\|}
\end{aligned}
$$

Untuk mendapat hyperplane terbaik digunakan rumus Quadratic Programming $(Q P)$ problem yang merupakan salah satu bentuk persamaan optimasi yang banyak digunakan dengan mengoptimalkan invers persamaan (2.3), yaitu

$$
\min \frac{1}{2}\|\mathbf{w}\|^{2} \text {, subject to } y_{i}\left(\mathbf{w}^{T} \mathbf{x}_{i}+b\right) \geq 1, i=1,2, . ., n
$$

Optimalisasi dipecahkan dengan teknik Lagrange Multiplier, yang menghasilkan

$$
L_{p}(\mathbf{w}, b, \boldsymbol{\alpha})=\frac{1}{2}\|\mathbf{w}\|^{2}-\sum_{i=1}^{n} \alpha_{i}\left(y_{i}\left(\mathbf{w}^{T} \mathbf{x}_{i}+b\right)-1\right)
$$

dengan $\alpha_{i}$ merupakan nilai Lagrange multiplier dengan nilai $\alpha_{i} \geq 0$. Kemudian $L_{p}$ diminimumkan dengan menurunkan parsial $L_{p}$ terhadap $\mathbf{w}$ dan $b$ lalu disamadengankan 0 . 


$$
\begin{gathered}
\frac{\partial}{\partial b} L_{p}(\mathbf{w}, b, \boldsymbol{\alpha})=0 \Rightarrow \mathbf{w}=\sum_{i=1}^{n} \alpha_{i} y_{i} \mathbf{x}_{i} \\
\frac{\partial}{\partial \mathbf{w}} L_{p}(\mathbf{w}, b, \boldsymbol{\alpha})=0 \Rightarrow \sum_{i=1}^{n} \alpha_{i} y_{i}=0
\end{gathered}
$$

$\|\mathbf{w}\|^{2}$ dijabarkan berdasarkan persamaan (2.6)

$$
\|\mathbf{w}\|^{2}=\mathbf{w}^{T} \mathbf{w}=\sum_{i=1}^{n} \alpha_{i} y_{i} \mathbf{x}_{i}^{T} \sum_{j=1}^{n} \alpha_{j} y_{j} \mathbf{x}_{j}=\sum_{i=1}^{n} \sum_{j=1}^{n} \alpha_{i} \alpha_{j} y_{i} y_{j}\left(\mathbf{x}_{i}^{T} \mathbf{x}_{j}\right)
$$

$L_{p}$ (primal problem) diubah ke dalam dual problem $L_{d}$ dengan mensubsitusikan persamaan (2.6), (2.7), dan (2.8) ke persamaan $L_{p}$ (2.5). Nilai optimal diperoleh dengan memaksimalkan $L_{d}$ terhadap $\alpha$ untuk mendapat pemisahan bidang terbaik (Wang, 2005):

$$
\max L_{d}=\max \left(\sum_{i=1}^{n} \alpha_{i}-\frac{1}{2} \sum_{i=1}^{n} \sum_{j=1}^{n} y_{i} y_{j} \alpha_{i} \alpha_{j}\left(\mathbf{x}_{i}^{T} \mathbf{x}_{j}\right)\right) \text {, dengan syarat } \sum_{i=1}^{n} \alpha_{i} y_{i}=0, \alpha_{i} \geq 0(i=1,2, \ldots, n)
$$

$\alpha_{i}>0$ adalah support vector, sisanya $\alpha_{i}=0$ tidak terletak di hyperplane (Nugroho et al., 2003).

\subsubsection{SVM Nonlinearly Separable Data}

Umumnya dua buah class pada input space tidak dapat terpisah secara sempurna, maka SVM dirumuskan ulang dengan memperkenalkan teknik softmargin. Dalam softmargin, persamaan (2.4) dimodifikasi dengan memasukkan slack variabel $\xi_{i} \quad\left(\xi_{i}>0\right)$.

$$
\begin{aligned}
& y_{i}\left(\mathbf{w}^{T} \mathbf{x}_{i}+b\right) \geq 1-\xi_{i}, i=1,2, . ., n, \xi_{i} \geq 0 \\
& \min _{w} \tau(\mathbf{w}, \boldsymbol{\xi})=\min \left(\frac{1}{2}\|w\|^{2}+C \sum_{i=1}^{n} \xi_{i}\right)
\end{aligned}
$$

Parameter $C$ (Cost) dipilih untuk mengontrol tradeoff antara margin dan error klasifikasi $\xi$. Nilai $C$ yang besar berarti akan memberikan penalti yang lebih besar terhadap error klasifikasi tersebut (Nugroho et al., 2003). Bentuk primal problem menjadi persamaan (2.11)

$$
L_{p}(\mathbf{w}, b, \boldsymbol{\xi}, \boldsymbol{\alpha}, \boldsymbol{\beta})=\frac{1}{2}\|\mathbf{w}\|^{2}+C \sum_{i=1}^{n} \xi_{i}-\sum_{i=1}^{n} \alpha_{i}\left(y_{i}\left(\mathbf{w}^{\mathbf{T}} \mathbf{x}_{\mathbf{i}}+b\right)\right)-1+\xi_{i}-\sum_{i=1}^{n} \beta_{i} \xi_{i}
$$

dimana $\alpha_{i}$ dan $\beta_{i}$ merupakan Lagrange multiplier. Optimasi $L_{p}$ dihitung dengan menurunkan $L_{p}$ terhadap $\mathbf{w}, \xi, b$ secara parsial lalu disamadengankan 0 , sehingga diperoleh sebagai berikut.

$$
\begin{aligned}
& \frac{\partial L}{\partial \mathbf{w}}=0 \Rightarrow \mathbf{w}=\sum_{i=1}^{n} \alpha_{i} y_{i} \mathbf{x}_{\mathbf{i}} \\
& \frac{\partial L}{\partial b}=0 \Rightarrow \sum_{i=1}^{n} \alpha_{i} y_{i}=0 \\
& \frac{\partial L}{\partial \xi}=0 \Rightarrow C-\alpha_{i}-\beta_{i}=0 \Rightarrow \alpha_{i}=C-\beta_{i}
\end{aligned}
$$

dari persamaan (2.12), (2.13) dan (2.14) diperoleh persamaan $L_{d}$ yang dimaksimalkan

$$
\max L_{d}=\max \left(\sum_{i=1}^{n} \alpha_{i}-\frac{1}{2} \sum_{i=1}^{n} \sum_{j=1}^{n} y_{i} y_{j} \alpha_{i} \alpha_{j}\left(\mathbf{x}_{i}^{T} \mathbf{x}_{j}\right)\right)
$$

dengan batas $0 \leq \alpha_{i} \leq C, i=1,2,3, \ldots, n$ dan $\sum_{i=1}^{n} \alpha_{i} y_{i}=0$ 
Karena masalah dunia nyata jarang bersifat linear, tetapi nonlinear, maka SVM dimodifikasi dengan memasukkan fungsi kernel, yaitu fungsi yang sering digunakan untuk mengubah data masukan menjadi berdimensi tinggi sehingga dapat dipisahkan (Wang, 2005).

Dalam SVM nonlinearly separable data, data $\vec{x}$ dipetakan oleh fungsi $\Phi(\vec{x})$ ke ruang vektor yang berdimensi lebih tinggi sehingga kedua kelas dapat dipisahkan secara linier oleh sebuah hyperplane. Notasi matematika dari mapping adalah sebagai berikut.

$$
\Phi: R^{d} \rightarrow R^{q} \quad d<q
$$

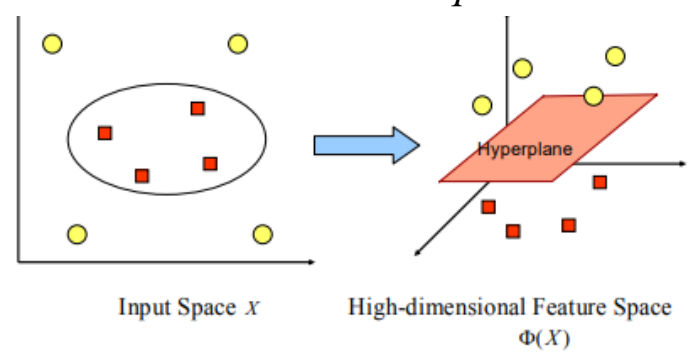

Gambar 1. Fungsi $\Phi$ memetakan data ke ruang dimensi tinggi (Nugroho et al., 2003)

Selanjutnya proses pembelajaran pada SVM dalam menemukan titik-titik support vector, hanya bergantung pada dot product dari data yang sudah ditransformasikan pada ruang berdimensi lebih tinggi, yaitu $\Phi\left(x_{i}\right) \Phi\left(x_{j}\right)$. Umumnya transformasi $\Phi$ sulit untuk dipahami, maka perhitungan dot product digantikan fungsi kernel yang biasa disebut Kernel Trick.

$$
K\left(x_{i}, x_{j}\right)=\Phi\left(x_{i}\right)^{T} \Phi\left(x_{j}\right)
$$

Fungsi kernel yang umum digunakan salah satunya kernel Radial Basis Function (RBF).

$$
K\left(x_{i}, x_{j}\right)=\exp \left(-\gamma\left\|x_{i}-x_{j}\right\|^{2}\right)
$$

dengan $x_{i}$ dan $x_{j}$ adalah pasangan dua data. $d$ adalah degree, makin tinggi maka batas keputusan yang lebih fleksibel. $\gamma$ adalah gamma, yaitu tingkat pembelajaran yang mengatur lebar kurva berbentuk lonceng, jika makin besar maka kurva makin sempit.

Selanjutnya hasil klasifikasi dari data $x$ diperoleh dari persamaan berikut (Nugroho et al., 2003)

$$
\begin{aligned}
& f(\Phi(\mathbf{x}))=\operatorname{sign}\left(\sum_{i=1}^{n s} \alpha_{i} y_{i} K\left(\mathbf{x}, \mathbf{x}_{i}\right)+b\right) \\
& f(\Phi(\mathbf{x}))=\left\{\begin{array}{l}
1, j i k a \sum_{i=1}^{n s} \alpha_{i} y_{i} K\left(\mathbf{x}, \mathbf{x}_{i}\right)+b \geq 0 \\
-1, j i k a \sum_{i=1}^{n s} \alpha_{i} y_{i} K\left(\mathbf{x}, \mathbf{x}_{i}\right)+b<0
\end{array}\right.
\end{aligned}
$$

$$
\begin{aligned}
& \text { dengan } f(\Phi(\mathbf{x})) \quad \text { : hasil klasifikasi dari data } \mathbf{x} \\
& y_{i} \quad: \text { kelas data } \\
& \alpha_{i} \quad \text { : koefisien lagrange } \\
& K\left(\mathbf{x}, \mathbf{x}_{i}\right) \quad \text { : fungsi kernel data uji dan data latih } \\
& \text { b : bias } \\
& \text { ns : banyak support vector }
\end{aligned}
$$




\subsection{Evaluasi Sistem Klasifikasi}

Suatu sistem klasifikasi harus dievaluasi agar dapat diketahui tingkat akurasi dari prediksi yang dihasilkan oleh sistem klasifikasi tersebut. Untuk proses evaluasi akurasi klasifikasi dilakukan dengan memperhatikan confusion matrix. Confusion matrix digambarkan dengan tabel jumlah data uji yang benar dan salah diklasifikasikan (Rahman et al., 2017).

Tabel 1. Confusion Matrix (Rahman et al., 2017)

\begin{tabular}{ccc}
\hline \multirow{2}{*}{ Corect Classification } & \multicolumn{2}{c}{ Classified as } \\
\cline { 2 - 3 } & Predicted "+” & Predicted “-“" \\
\hline Actual “+” & True Positives & False Negatives \\
Actual “_" & False Positives & True Negatives \\
\hline
\end{tabular}

dengan True Positives (TP) : banyak record data positif yang diklasifikasikan positif

False Positives (FP) : banyak record data negatif yang diklasifikasikan positif

False Negatives (FN) : banyak record data positif yang diklasifikasikan negatif

True Negatives (TN) : banyak record data negatif yang diklasifikasikan negatif.

Tabel 2. Ukuran Evaluasi Model Klasifikasi

\begin{tabular}{cc}
\hline Ukuran & \multicolumn{1}{c}{ Rumus } \\
\hline Accuracy & $\frac{T P+T N}{T P+T N+F P+F N}$ \\
& $P_{0}=$ Accuracy \\
Kappa statistic & $\mathrm{P}_{c}=\left[\left(\frac{T P+F P}{\text { Total }}\right)\left(\frac{T P+F N}{\text { Total }}\right)\right]+\left[\left(\frac{F N+T N}{\text { Total }}\right)\left(\frac{F P+T N}{\text { Total }}\right)\right]$ \\
& $K=\frac{P_{0}-\mathrm{P}_{c}}{\left(1-\mathrm{P}_{c}\right)}$ \\
\hline
\end{tabular}

\subsection{Asosiasi}

Asosiasi adalah hubungan antara dua variabel, yaitu antarkata pada ulasan sehingga mendapat informasi sebagai bahan rujukan dalam proses evaluasi aplikasi. Nilai asosiasi yang besar berarti korelasi semakin besar dan menunjukkan kata-kata tersebut sering muncul bersamaan dalam satu kalimat (Santosa dan Nugroho, 2019).

$$
r_{x y}=\frac{n\left(\sum_{i=1}^{n} X_{i} Y_{i}\right)-\left(\sum_{i=1}^{n} X_{i}\right)\left(\sum_{i=1}^{n} Y_{i}\right)}{\sqrt{\left\{n \sum_{i=1}^{n} X_{i}^{2}-\left(\sum_{i=1}^{n} X_{i}\right)^{2}\right\}\left\{n \sum_{i=1}^{n} Y_{i}^{2}-\left(\sum_{i=1}^{n} Y_{i}\right)^{2}\right\}}}
$$

$$
\begin{aligned}
& \text { dengan } r_{x y} \quad \text { : Nilai korelasi antara variabel } x \text { dan variabel } y \\
& n \quad \text { : Banyaknya pasangan data } x \text { dan } y \\
& \sum_{i=1}^{n} x_{i} \quad \text { : Jumlah nilai pada variabel } x \text { atau variabel pertama } \\
& \sum_{i=1}^{n} Y_{i} \quad: \text { Jumlah nilai pada variabel } y \text { atau variabel kedua } \\
& \sum_{i=1}^{n} X_{i}^{2} \quad: \text { Kuadrat dari total nilai variabel } x \\
& \sum_{i=1}^{n} Y_{i}^{2} \quad: \text { Kuadrat dari total nilai variabel y } \\
& \sum_{i=1}^{n} X_{i} Y_{i} \quad \text { : Jumlah dari hasil perkalian antara nilai variabel } x \text { dan } \mathrm{y}
\end{aligned}
$$




\section{METODE PENELITIAN}

\subsection{Sumber Data dan Variabel Penelitian}

Jenis data yang digunakan adalah data sekunder, yaitu data ulasan bahasa Indonesia aplikasi TikTok di Google Play Store pada bulan September 2020 hingga Februari 2021 sebanyak 3200 ulasan. Pengumpulan data menggunakan teknik web scraping, yaitu pengambilan sebuah dokumen semi-terstruktur dari halaman web (Ayani et al., 2019). Variabel yang digunakan adalah tanggal memberi ulasan, nama akun Google, dan ulasan pengguna.

\subsection{Langkah-langkah Analisis}

Penelitian dilakukan dengan bantuan software Data Miner untuk web scrapping dan Rstudio untuk analisis data. Adapun tahapan-tahapan analisis yang dilakukan:

1. Scraping data ulasan aplikasi TikTok di Google Play

2. Analisis deskriptif data ulasan aplikasi TikTok di Google Play.

3. Pre-processing data (case folding, cleaning, dan normalisasi kata).

4. Pelabelan data dengan sentiment scoring.

5. Feature selection (stopwords, stemming, dan tokenizing)

6. Pembobotan TF-IDF

7. Pembuatan data latih dan data uji dengan perbandingan 80\%:20\%

8. Membangun model klasifikasi Suport Vector Machine dengan fungsi kernel RBF

9. Menghitung akurasi dan kappa menggunakan confusion matrix dari data uji untuk mengevaluasi model klasifikasi

10. Membuat asosiasi teks

11. Interpretasi hasil.

\section{HASIL DAN PEMBAHASAN}

\subsection{Pengumpulan Data}

Pengumpulan data ulasan TikTok di Google Play menggunakan metode scraping data dengan aplikasi Data Miner. Data yang diambil berisi tanggal, nama, dan ulasan yang disimpan dalam bentuk Comma Separated Value (CSV). Berikut banyak data ulasan TikTok per bulan.

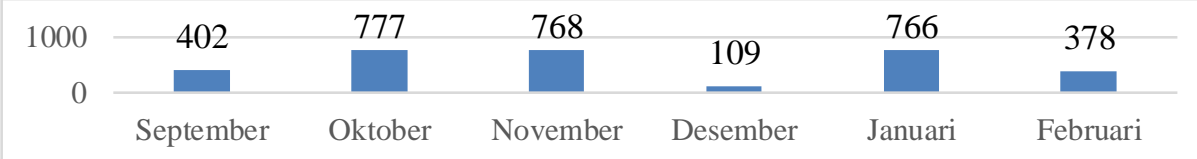

Gambar 2. Histogram banyak ulasan TikTok per bulan

\subsection{Pre-Processing Data}

Preprocessing data dilakukan untuk mengubah data tidak terstruktur menjadi terstruktur

Tabel 3. Contoh proses pre-processing data

\begin{tabular}{lll}
\hline \multicolumn{1}{c}{ Proses } & \multicolumn{1}{c}{ Sebelum } & \multicolumn{1}{c}{ Sesudah } \\
\hline Case folding & Apk ini bagus banget!!!!!!!!!!!!! & apk ini bagus banget!!!!!!!!!!!!! \\
Cleaning & apk ini bagus banget!!!!!!!!!!!! & apk ini bagus banget \\
Normalisasi & apk ini bagus banget & aplikasi ini bagus banget \\
\hline
\end{tabular}

\subsection{Pelabelan Data dengan Sentiment Scoring}

Pada proses pelabelan data dengan sentiment scoring menggunakan dua kamus, yaitu kamus boosterwords dan kamus sentimen dengan ketentuan menghitung skor sebagai berikut. 1. Kamus sentimen berisi kata berserta skor yang diberikan. Kata yang tidak terdapat pada 
kamus sentimen diberi nilai 0. Contoh: kata "baik" bernilai 4, kata "buruk" bernilai -4, kata "ada" tidak terdapat pada kamus sentimen, maka bernilai 0.

2. Kamus boosterwords digunakan dengan melihat skor pada kamus sentimen. Jika kata pada kamus sentimen $>0$ dan diikuti kata boosterwords, maka skor ditambahkan. Sebaliknya, jika kata pada kamus sentimen $<0$ dan diikuti kata boosterwords, maka skor dikurangi.

3. Pada kalimat yang mengandung kata negasi, akan dilakukan replace dengan lawan katanya, seperti "tidak bagus" diganti dengan "jelek" dan sebaliknya "tidak jelek" diganti "bagus".

4. Ulasan dengan total skor akhir $\geq 0$ maka akan diberi label positif, sedangkan ulasan dengan total skor akhir $<0$ maka akan diberi nilai negatif.

Contoh perhitungan sentiment scoring adalah sebagai berikut.

\begin{tabular}{|lll|}
\hline aplikasi ini bagus banget & bagus (kamus sentimen) & $=1$ \\
& banget (boosterwords) & $=4$ \\
& Total skor & $\mathbf{= 5}$ (positif) \\
\hline
\end{tabular}

Gambar 3. Contoh perhitungan sentiment scoring

Hasil pelabelan dari 3200 terdiri dari 1741 sentimen positif dan 1459 sentimen negatif.

\subsection{Feature Selection}

\subsubsection{Stopwords Removal}

Stopwords yang digunakan dalam penelitian ini sebanyak 875 kata. Dengan dilakukan proses stopwords removing jumlah term dalam dokumen menjadi berkurang.

\subsubsection{Stemming}

Stemming merupakan tahap mengubah kata-kata dalam dokumen teks menjadi kata dasar. Stemming pada software $\mathrm{R}$ dilakukan dengan menggunakan package katadasaR.

Tabel 4. Hasil Stemming

\begin{tabular}{cl}
\hline Ulasan ke- & \multicolumn{1}{c}{ Ulasan } \\
\hline 1 & suka main tiktok main tiktok seru iya main tiktok seru terimakasih aplikasi \\
2 & tiktok pandemi covid main tiktok biar hibur \\
\hline
\end{tabular}

\subsubsection{Tokenizing}

Tokenizing merupakan tahap pemisahan setiap kata dalam suatu kalimat. Tujuan tokenizing adalah memotong kalimat berdasarkan tiap kata yang menyusun kalimat tersebut.

4.5. Pembobotan Term Frequency-Inverse Document Frequency (TF-IDF)

Term frequency (tf) untuk mengukur frekuensi kemunculan kata dalam setiap ulasan. Ketika tf tinggi yang berarti term sering muncul dalam ulasan. Berikut hasil perhitungan $t f$

Tabel 5. Hasil perhitungan term frequency (tf)

\begin{tabular}{ccccccccc}
\hline Ulasan ke & aba & $\ldots$ & aplikasi & $\ldots$ & bagus & $\ldots$ & zoom & Jumlah term \\
\hline 1 & 0 & $\ldots$ & 1 & $\ldots$ & 0 & $\ldots$ & 0 & 19 \\
2 & 0 & $\ldots$ & 1 & $\ldots$ & 1 & $\ldots$ & 0 & 3 \\
$\vdots$ & $\vdots$ & $\vdots$ & $\vdots$ & $\vdots$ & $\vdots$ & $\ddots$ & $\vdots$ & $\vdots$ \\
3200 & 0 & $\ldots$ & 0 & $\ldots$ & 0 & $\ldots$ & 0 & 10 \\
\hline Jumlah dok & 1 & $\ldots$ & 1634 & $\ldots$ & 835 & $\ldots$ & 8 &
\end{tabular}

Contoh perhitungan pembobotan TF-IDF. 
$\mathrm{w}_{\text {aplikasi,dok } 1}=\frac{\text { jumlah term di dok }}{\text { jumlah seluruh term di dok }} \times \log _{2} \frac{\text { jumlah seluruh dok }}{\text { jumlah dok pada term }}=\frac{1}{19} \times \log _{2} \frac{3200}{1634}=0,051$

Tabel 6. Hasil pembobotan dengan Term Frequency-Inverse Document Frequency

\begin{tabular}{cccccccc}
\hline Ulasan ke & aba & $\ldots$ & aplikasi & $\ldots$ & bagu s & $\ldots$ & zoom \\
\hline 1 & 0 & $\ldots$ & 0,051 & $\ldots$ & 0 & $\ldots$ & 0 \\
2 & 0 & $\ldots$ & 0,323 & $\ldots$ & 0,646 & $\ldots$ & 0 \\
$\vdots$ & $\vdots$ & $\vdots$ & $\vdots$ & $\vdots$ & $\vdots$ & $\ddots$ & $\vdots$ \\
3200 & 0 & $\ldots$ & 0 & $\ldots$ & 0 & $\ldots$ & 0 \\
\hline
\end{tabular}

\subsection{Klasifikasi}

\subsubsection{Pembuatan Data Latih dan Data Uji}

Data latih dan data uji yang digunakan adalah data pembobotan TF-IDF beserta label kelas, dengan perbandingan data uji dan data latih adalah 20\%:80\%. Pembuatan data latih dan data uji dilakukan dengan asumsi bahwa setiap data ulasan punya peluang yang sama untuk dapat digunakan sebagai data uji maupun data latih. Maka pemilihan data uji dan data latih berdasarkan urutan ulasan, yaitu dari total 3200 data ulasan, digunakan sebanyak 2560 data ulasan pertama sebagai data latih dan sisanya sebanyak 640 data sebagai data uji.

\subsubsection{Klasifikasi Support Vector Machine (SVM)}

Pada penelitian ini digunakan metode SVM dengan fungsi kernel Radial Basis Function (RBF). Pada kernel RBF terdapat dua parameter yaitu nilai Cost dan gamma. Pengoptimalan parameter $\mathrm{C}$ dapat dilakukan dengan cara trial and error. Nilai Cost (C) yang digunakan adalah 0,01; 0,1; 1 10, 100, 1000 dan gamma sesuai nilai default, yaitu $\gamma=\frac{1}{n c o l}=\frac{1}{2350}=0,0004255319$.

Proses SVM dalam menemukan titik-titik support vector, hanya bergantung pada dot product dari data yang sudah ditransformasikan pada ruang baru yang berdimensi lebih tinggi. Untuk menentukan dot product dilakukan dengan memasukkan kernel RBF pada setiap data. Seluruh data dihitung dengan cara sama sehingga menghasilkan nilai kernel yang membentuk matrix berukuran $2560 \times 2560$. Contoh perhitungan fungsi kernel $\mathrm{RBF}$ pada data latih.

$$
\begin{aligned}
& K\left(x_{i}, x_{j}\right)=\exp \left(-\gamma\left\|x_{i}-x_{j}\right\|^{2}\right)=\exp \left(-\gamma \sum_{j=1}^{n}\left(x_{i}-x_{j}\right)^{2}\right) \\
& K\left(x_{1}, x_{1}\right)=\exp \left(-0.0004255319\left(\begin{array}{l}
(0-0)^{2}+\ldots+(0-0)^{2}+(0-0)^{2}+(0-0)^{2}+(0-0)^{2} \\
+(0-0)^{2}+(0-0)^{2}+(0-0)^{2}+\ldots+(0-0)^{2}
\end{array}\right)\right)=1
\end{aligned}
$$

Selanjutnya dicari nilai $\boldsymbol{\alpha}$ dan $b$ paling optimal dengan Quadratic Programming (QP) pada $\operatorname{Cost}(\mathrm{C})$ yang dicoba, yaitu 0,$01 ; 0,1 ; 1 ; 10 ; 100 ; 1000$ dengan bantuan software Rstudio untuk memprediksi klasifikasi data uji. Dot product data latih dan data uji diperoleh dengan cara yang sama, yaitu memasukkan data uji ke data latih dalam fungsi kernel RBF sehingga menghasilkan matriks kernel ukuran $2560 \times 640$

Tabel 7. Nilai $\boldsymbol{\alpha}$ dan $b$ pada tiap nilai $\mathrm{C}$

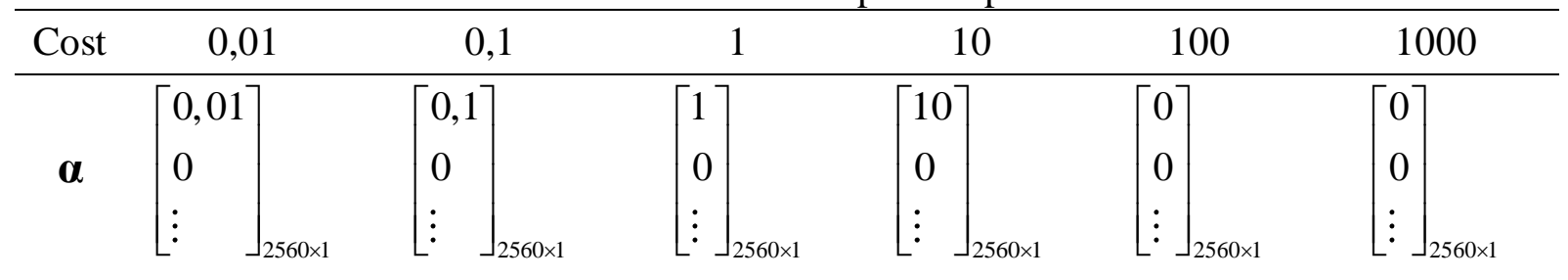


$\begin{array}{lllllll}b & -0,9993469 & -0,9934695 & -0,927911 & -0,3033061 & 2,071065 & 1,503933\end{array}$

Untuk C=0,01, persamaan untuk SVM kernel RBF adalah sebagai berikut.

$y_{i}=\operatorname{sign}\left(\sum_{i=1}^{n s} \alpha_{i} y_{i} K\left(\mathbf{x}, \mathbf{x}_{i}\right)+b\right)=\operatorname{sign}\left(\sum_{i=1}^{n s} \alpha_{i} y_{i} K\left(\mathbf{x}_{\text {training }}, \mathbf{x}_{\text {testing }}\right)+b\right)=\operatorname{sign}\left(\sum_{i=1}^{n s} \alpha_{i} y_{i} K\left(\mathbf{x}_{\text {training }}, \mathbf{x}_{\text {testing }}\right)-0,9993469\right)$

$y_{\text {ulasan } 2561}=\operatorname{sign}\left(\sum_{i=1}^{n s} \alpha_{i} y_{i} K\left(\mathbf{x}_{\text {training }}, \mathbf{x}_{2561}\right)-0,9993469\right)$

$y_{\text {ulasan } 2561}=\operatorname{sign}([(0,01 \times 1 \times 1)-0,9993469]+[(0 \times 1 \times 1)-0,9993469]+\ldots)=-1$

Perhitungan yang sama dilakukan untuk semua data uji pada tiap $\mathrm{C}$ yang digunakan.

Untuk mengukur performa model klasifikasi, dapat dilihat confusion matrix data uji hasil output software R yang merupakan proses klasifikasi SVM kernel RBF di setiap C.

Tabel 8. Confusion Matrix

\begin{tabular}{ccccccccccccc}
\hline & \multicolumn{1}{c}{$\mathbf{C = 0 , 0 1}$} & \multicolumn{2}{c}{$\mathbf{C = 0 , 1}$} & \multicolumn{2}{c}{$\mathbf{C = 1}$} & \multicolumn{2}{c}{$\mathbf{C = 1 0}$} & \multicolumn{2}{c}{$\mathbf{C = 1 0 0}$} & \multicolumn{2}{c}{$\mathbf{C = 1 0 0 0}$} \\
\hline \multirow{2}{*}{ Prediksi $=\mathbf{1 0}$} & \multicolumn{2}{c}{ Aktual } & \multicolumn{2}{c}{ Aktual } & \multicolumn{2}{c}{ Aktual } & \multicolumn{2}{c}{ Aktual } & \multicolumn{2}{c}{ Aktual } & \multicolumn{2}{c}{ Aktual } \\
\cline { 2 - 15 } & $\mathbf{N}$ & $\mathbf{P}$ & $\mathbf{N}$ & $\mathbf{P}$ & $\mathbf{N}$ & $\mathbf{P}$ & $\mathbf{N}$ & $\mathbf{P}$ & $\mathbf{N}$ & $\mathbf{P}$ & $\mathbf{N}$ & $\mathbf{P}$ \\
\hline $\mathbf{N}$ & 277 & 47 & 284 & 61 & 286 & 66 & 286 & 67 & 282 & 36 & 272 & 39 \\
$\mathbf{P}$ & 29 & 287 & 22 & 273 & 20 & 268 & 20 & 267 & 24 & 298 & 34 & 295 \\
\hline
\end{tabular}

Contoh perhitungan accuracy dan kappa pada confusion matrix $\mathrm{C}=0,01$

Accuracy $=\frac{\text { prediksi databenar }}{\text { total data }}=\frac{T P+T N}{T P+T N+F P+F N}=\frac{287+277}{287+277+29+47}=0,8812$

Kappa $=\frac{P_{0}-\mathrm{P}_{c}}{\left(1-\mathrm{P}_{c}\right)}=\frac{0,8812-0,4997}{(1-0,4997)}=0,7626$

Berdasarkan perhitungan accuracy dan kappa pada nilai C sebesar 0,$01 ; 0,1 ; 1 ; 10 ; 100$; 1000 yang telah dilakukan. Tabel hasil percobaan performa kernel RBF dengan nilai gamma tetap dan berbagai nilai Cost (C) adalah sebagai berikut.

Tabel 9. Nilai Accuracy dan Kappa pada Kernel RBF

\begin{tabular}{ccccccc}
\hline Evaluasi & \multicolumn{6}{c}{ Cost (C) } \\
\cline { 2 - 7 } Model & $\mathbf{0 , 0 1}$ & $\mathbf{0 , 1}$ & $\mathbf{1}$ & $\mathbf{1 0}$ & $\mathbf{1 0 0}$ & $\mathbf{1 0 0 0}$ \\
\hline Accuracy & 0,8812 & 0,8703 & 0,8656 & 0,8641 & 0,9062 & 0,8859 \\
Kappa & 0,7626 & 0,7415 & 0,7324 & 0,7293 & 0,8124 & 0,7716 \\
\hline
\end{tabular}

Maka nilai C yang paling optimal adalah 100, dengan nilai accuracy 0,9062 dan kappa 0,8124.

\subsection{Visualisasi dan Asosiasi}

Visualisasi data ulasan TikTok dilakukan pada masing-masing kelas untuk mengambil informasi tentang topik yang sering dibicarakan. Ulasan diidentifikasi berdasarkan banyaknya frekuensi kata tertinggi yang merupakan topik pembicaraan paling banyak ditulis pengguna. Berikut merupakan hasil visualisasi ulasan positif dan negatif. 

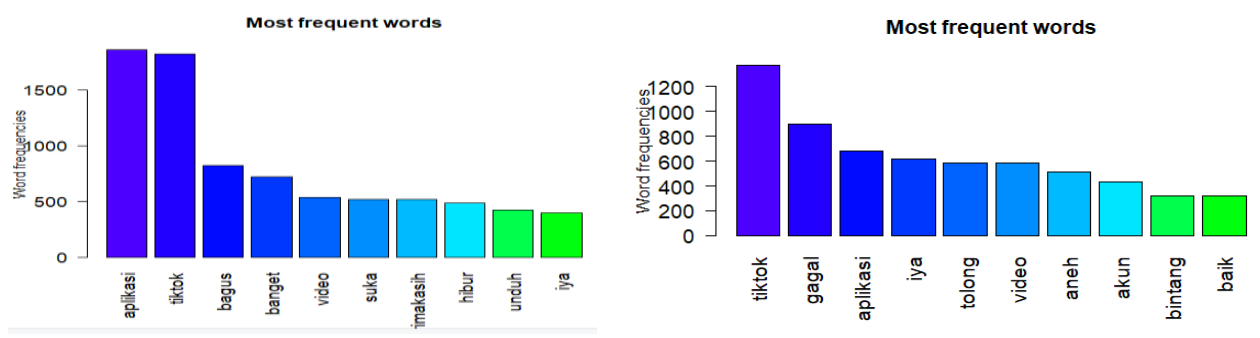

Gambar 4. Histogram kata frekuensi terbanyak ulasan positif dan negatif Asosiasi kata dari sepuluh kata paling sering muncul dengan batas bawah nilai asosiasi adalah 0,2 yang dianggap cukup menunjukkan besar hubungan antarkata berdasarkan kondisi data.

\begin{tabular}{lllllllll}
\multicolumn{7}{c}{ Tabel 10. Asosiasi kata positif } \\
\hline \multicolumn{2}{c}{ aplikasi } & \multicolumn{2}{c}{ tiktok } & \multicolumn{2}{c}{ bagus } & \multicolumn{2}{c}{ banget } & \multicolumn{2}{c}{ video } \\
\hline semat & 0,32 & terimakasih & 0,21 & - & unduh & 0,24 & fyp & 0,23 \\
bikin & 0,24 & & & & pokok & 0,21 & lucu & 0,23 \\
versi & 0,23 & & & & suka & 0,2 & & \\
\hline \multicolumn{2}{c}{ suka } & \multicolumn{2}{c}{ terimakasih } & hibur & \multicolumn{2}{c}{ unduh } & iya \\
\hline banget & 0,2 & semoga & 0,23 & - & buru & 0,36 & - \\
& & nyaman & 0,22 & & sesal & 0,32 & \\
& & tiktok & 0,21 & & ayo & 0,24 & \\
\hline
\end{tabular}

\begin{tabular}{|c|c|c|c|c|c|c|c|c|c|}
\hline \multicolumn{10}{|c|}{ Tabel 11. Asosiasi kata negatif } \\
\hline \multicolumn{2}{|c|}{ tiktok } & \multicolumn{2}{|c|}{ gagal } & \multicolumn{2}{|c|}{ aplikasi } & \multicolumn{2}{|c|}{ iya } & \multicolumn{2}{|c|}{ tolong } \\
\hline tiktoker & 0,23 & syarat & 0,31 & bagus & 0,25 & - & & baik & 0,37 \\
\hline cipta & 0,21 & daftar & 0,27 & jelek & 0,22 & & & tiktoker & 0,27 \\
\hline & & lahir & 0,25 & & & & & cipta & 0,23 \\
\hline & & tanggal & 0,25 & & & & & & \\
\hline & & masuk & 0,23 & & & & & & \\
\hline & & coba & 0,21 & & & & & & \\
\hline \multicolumn{2}{|c|}{ video } & \multicolumn{2}{|c|}{ aneh } & \multicolumn{2}{|c|}{ akun } & \multicolumn{2}{|c|}{ bintang } & \multicolumn{2}{|c|}{ baik } \\
\hline \multirow[t]{3}{*}{ unggah } & 0,27 & - & & kembali & 0,26 & kasih & 0,66 & tolong & 0,37 \\
\hline & & & & blokir & 0,24 & dislike & 0,27 & & \\
\hline & & & & & & maaf & 0,24 & & \\
\hline
\end{tabular}

Contoh perhitungan asosiasi kata "video" dan "fyp" berdasarkan nilai if pada kelas positif.

$$
r_{X Y}=\frac{n\left(\sum_{i=1}^{n} X_{i} Y_{i}\right)-\left(\sum_{i=1}^{n} X_{i}\right)\left(\sum_{i=1}^{n} Y_{i}\right)}{\sqrt{\left\{n \sum_{i=1}^{n} X_{i}^{2}-\left(\sum_{i=1}^{n} X_{i}\right)^{2}\right\}\left\{n \sum_{i=1}^{n} Y_{i}^{2}-\left(\sum_{i=1}^{n} Y_{i}\right)^{2}\right\}}}=\frac{(1741 \times 160)-(177)(537)}{\sqrt{\left\{(1741 \times 281)-(177)^{2}\right\}\left\{(1741 \times 995)-(537)^{2}\right\}}}=0,23
$$

Informasi yang bisa dibangun dari asosiasi kata di ulasan positif adalah pengguna yang memberikan ulasan positif karena suka sekali dengan aplikasi TikTok versi sekarang yang berisi video-video lucu di fyp atau beranda TikTok. Pengguna menyatakan tidak menyesal telah mengunduh TikTok dan mengajak pembaca untuk mengunduh juga. Pengguna berterima kasih karena merasa nyaman menggunakan aplikasi TikTok.

Sedangkan, informasi yang bisa dibangun dari asosiasi kata di ulasan negatif adalah pengguna yang memberikan ulasan negatif karena gagal mencoba daftar atau masuk akun disebabkan tidak terpenuhinya syarat tanggal lahir. Pengguna tidak menyatakan TikTok jelek 
secara keseluruhan, tapi juga mengakui ada bagian yang bagus. Pengguna meminta pihak TikTok mengembalikan akunnya yang diblokir. Pengguna yang memberikan ulasan negatif meminta maaf karena memberikan dislike atau sedikit bintang penilaian di Google Play. Pengguna TikTok meminta tolong pihak TikTok dan TikToker (sebutan untuk para pencipta atau pengunggah video di TikTok) bisa membuka TikTok menjadi semakin baik.

\section{KESIMPULAN}

Berdasarkan analisis dan pembahasan didapatkan beberapa kesimpulan sebagai berikut.

1. Persepsi pengguna TikTok berdasarkan pelabelan sentimen ulasan bulan September 2020 sampai Februari 2021 di Google Play sebanyak 3200 ulasan adalah jumlah ulasan positif lebih banyak, yaitu 1741 (54,41\%) dibanding jumlah ulasan negatif, yaitu 1459 (45,59\%).

2. Klasifikasi sentimen dari hasil sentiment scoring ulasan aplikasi TikTok di Google Play menggunakan metode Support Vector Machine (SVM) kernel RBF dengan perbandingan data latih dan data uji sebesar 80 : 20 menghasilkan tingkat accuracy dan kappa terbaik sebesar 90,62\% dan 81,24\% yang berarti termasuk hasil klasifikasi yang hampir sempurna.

3. Berdasarkan hasil klasifikasi dan asosiasi, pengguna memberikan ulasan positif karena suka sekali dengan TikTok versi sekarang yang berisi video-video lucu di fyp atau beranda TikTok. Pengguna menyatakan bahwa tidak menyesal telah mengunduh TikTok dan mengajak pembaca untuk mengunduh juga. Sedangkan pada kelas sentimen negatif, pengguna memberikan ulasan negatif karena gagal dalam mencoba daftar atau masuk ke akun TikTok karena tidak memenuhi syarat tanggal lahir. Pengguna meminta pihak TikTok mengembalikan akunnya yang diblokir. Pengguna yang memberi ulasan negatif biasanya juga memberikan dislike atau sedikit bintang penilaian di Google Play serta meminta tolong pihak TikTok dan TikToker (sebutan untuk para pencipta atau pengunggah video di TikTok) bisa membuat TikTok menjadi semakin baik.

\section{DAFTAR PUSTAKA}

Ayani, D. D., Pratiwi, H. S.,dan Muhardi, H. 2019. Implementasi Web Scraping untuk Pengambilan Data pada Situs Marketplace. Sistem dan Teknologi Informasi Vol 7, No 4, Hal. 257-262.

Christian, H., Agus, M. P., dan Suhartono, D. 2016. Single Document Automatic Text Summarization Using Term Frequency-Inverse Document Frequency(TF-IDF). ComTech,Vol.7, Hal.285-294.

CNN, 2018. Penuhi 9 dari 10 Syarat Kominfo, Blokir TikTok Dibuka. https://www.cnnindonesia.com/teknologi/20180710162606-185-313025/penuhi-9-dari-10syarat-kominfo-blokir-tik-tok-dibuka. Diakses: 2 September 2020.: s.n.

Fatmawati dan Affandes, M.. 2017. Klasifikasi Keluhan Menggunakan Metode Support Vector Machine (SVM) (Studi Kasus : Akun Facebook Group iRaise Helpdesk). Jurnal CoreIT, Vol.3, No.1, Hal. 24-30.

Indraloka, D. S. dan Santosa, B. 2017. Penerapan Text Mining untuk Melakukan Clustering Data Tweet Shopee Indonesia. JURNAL SAINS DAN SENI ITS Vol. 6, No. 2.

Liputan 6. 2020. Orang Indonesia Kedua Paling Banyak Unduh TikTok per Juli 2020. https://www.liputan6.com/tekno/read/4324103/orang-indonesia-kedua-paling-banyak-unduhtiktok-per-juli-2020. Diakses: 31 Agustus 2020.

Liu, B. 2015. Sentiment Analysis Mining Opinions, Sentiments, and Emotions. New York: Cambridge University Press.

Nugroho, A. S., Witarto, A. B., dan Handoko, D. 2003. Support Vector Machine Teori dan Aplikasinya dalam Bioinformatika. https://www.academia.edu/24381027/Support_Vector _Machine_Teori_dan_Aplikasinya_dalam_Bioinformatika_1. Diakses: 5 November 2020. 
Rahman, M., Darmawidjadja, Alamsah, D. 2017. Klasifikasi Untuk Dianosa Diabetes Menggunakan Metode Bayesian Regularization Neural Network(RBNN). Informatika, Vol 11, No 1.

Santosa, E. B. \& Nugroho, A. 2019. Analisis Sentimen Calon Presiden Indonesia 2019 Berdasarkan Komentar Publik di Facebook. Eksplora Informatika, Hal 60-69.

Wahid dan Azhari. 2016. Peringkasan Sentimen Esktraktif di Twitter Menggunakan Hybrid TF-IDF dan Cosine Similarity. Indonesian Journal of Computing \& Cybernetics Systems, Vol 10, No 2.

Wang, L. 2005. Support Vector Machines: Theory and Applications. Berlin: Springer. 